\title{
The life-world of mothers who care for mentally retarded children: the Katutura township experience
}

\author{
AM Ntswane, M Soc.Sc. Nursing \\ Nursing Department, University of Pretoria \\ L van Rhyn, Ph.D. \\ School of Nursing, University of Free State
}

Keywords: mentally retarded child; mother; feelings, caring

\section{Correspondence address:}

Annette Ntswane

No. 16 Corvette Avenue

Kenleaf Ext. 9

Brakpan

1541

\section{Abstract: Curationis 30(1): 85-96}

This article reports on a research study done in Katutura Township, near Windhoek. A qualitative, exploratory, descriptive and contextual design was followed to answer the research question investigating experiences of mothers caring for mentally retarded children at home. Phenomenological interviews were conducted with a purposefully selected sample of twelve mothers. The meaning of their experiences was analysed by using Tesch $\times$ s method (1990 in Creswell, 1994:155) of analysing qualitative data. The results indicated various emotions and challenges experienced by these mothers during the care of their children. Feelings of shock, despondency and sadness dominated the early stages when the retarded children were still young. During later years, as the children were growing up, the mothers felt shame, fear, frustration, anger, disappointment and worry. However, acceptance followed, as the children grew older. Stigma seemed to affect all the respondents. Support in any form or lack thereof seemed to be the decisive factor-positioning mothers along a continuum of two extremes, namely despairing isolation and integrated happiness. Recommendations were made regarding the improvement of heath care services and education of the mothers and their families.

\section{Opsomming}

Hierdie artikel raporteer bevindinge van ? navorsingstudie wat in die Katutura dorpsgebied naby Windhoek, gedoen is. ? Kwalitatiewe. Eksplorerende, beskrywende en kontekstueel ondersoekende ontwerp is gevolg, om die navorsingsvraag, wat die ondervindinge van moeders wat verstandelik vertraagde kinders tuis versorg, ondersoek het. Fenomologiese onderhoude is met? doelgerigte steekproef van twaalf moeders gevoer. Dic betekenis van hulle ervaring is geanaliseer deur gebruik te maak van Tesch (1990) se metode vir die analiseering van kwalitatiewe data. Die resultate het verskeie emosies en uitdagings, wat hierdie moeders gedurende die omsien na hulle kinders ervaar het, aan die lig gebring. Gevoelens van skod, wanhoop en verdriet het die eerste stadia, toe die kinders nog jonk was, oorheers. Gedurende die later jare, toe die kinders begin groter/ouer word, het die moeders skaam en bang gevoel en ook frustrasie, woede, teleurstelling en bekommernis ervaar. Aanvaarding het egter gevolg na mate die kinders ouer geword het. Dit lyk asof stigma al die respondente beinvloed het. Dit lyk ook asof ondersteuning van enige aard, of die afwesigheid daarvan, die deurslaggewende factor was, wat moeders op ? spesifieke posissie langs'? kontinuum van twee uiterstes, naamlik wanhopige isolasie en geintegreerde geluk, geplaas het. Aanbevelings ten opsigte van die verbetering van gesondheidsorgdienste en opleiding van die moeders en hul families, was gemaak. 


\section{Introduction}

Like all other developing and even developed countries, Namibia has a significant incidence of mental retardation in children. In a study conducted by Sartorius and Graham (1984:208) in eight developing countries in Asia. South America and West Africa to investigate child mental health, it was found that 13-18\% of children who presented at health care services in rural areas at that stage suffered from one or another form of mental disorder. The investigation further revealed that in urban slum areas the incidence was between $25-30 \%$ or higher. Baumann (1998:375) observed that when a mother has to care for a mentally retarded child, she suffers great levels of stress. In addition, she may experience loss of earnings from having to give up work to care for the child.

In Namibia, the impact of caring for a mentally retarded child on the mother is still unknown. In 1998, the Ministry of Health and Social Services of the country established a mental health programme under the Directorate of Primary Health Care (GRN/MHSS 002/1998). This programme undertook a national needs assessment survey of major mental health problems like schizophrenia, major depressive disorders, anxiety disorders and bipolar disorders, but mental retardation among children was not included. Although the Windhoek State Hospital has always had a psychiatric unit, this served only the adult population of mentally ill patients. Only mentally retarded children who present with behaviour problems would be seen occasionally, but as outpatients. The interventions afforded to this latter group were mainly curative. Neuroleptic treatment would be given to stabilise the child, who would then afterwards be sent him/her home to be cared for by the family. There is much work envisaged in mental health care within the primary health care approach in Namibia. Vranckx (1996:2) noted that in future the focus will cogently not only be on major psychiatric disorders, but also on emotional factors that place an adaptive strain on individuals, thus leading to maladaptive behaviour. Caring for a mentally retarded child at home may be an obvious strain on the mother. There is an apparent lack of knowledge about the experiences of mothers who care for mentally retarded children in Namibia. and especially in the townships.
In 2000, a non-governmental organisation called Children with Handicaps in Namibia (CHAIN) opened a day care centre in Katutura and Khomasdal to assist children from these townships. Taimi Nangombe, the head of the centre, told a newspaper reporter at the launch of the centre that the group of 46 accommodated at the centre at that stage were but a small number of the many in the township whose mothers were demanding institutional care, because of the inherent burdens in caring for these children at home. The present study on which this article is based, sought to explore by means of qualitative research the experiences of mothers in the Katutura Township, near Windhoek who care for their mentally retarded children at home. The study significantly broadened the knowledge and the understanding of the hardships borne by mothers in caring for their mentally retarded children at home. A set of guidelines was developed from the outcome of the study for supporting this population of mothers and their children. These guidelines would also assist the mental health programme of the Ministry of Health and Social Services regarding services planned for this group.

\section{Problem statement}

Having a mentally retarded child brings strain and frustration to the mothers. Some mothers lose their social life completely and their husbands or partners reject them because the child is mentally retarded. The rejection by their partners often leads to further the mothers' emotional distress and social isolation. Literature indicates that the impact of caring for mentally retarded children is the greatest challenge facing families. A study by Katwishi (1998:1), which was conducted in Zambia, investigated the impact of impairments of child development. Observations made were that it was a great challenge to families most of whom "live in the pockets of poverty". Lea (1989:256) studied the impact of raising a handicapped child, and identified emotional phases, which families exhibit in response to the child's handicap. Other studies found that having a mentally retarded child is an emotional issue and one which can cause acute upset and anxiety for parents, even several years after discovering that the child is retarded (Leadbetter \& Leadbetter, 1993:117; Lacey \& Ouvry, 1998:168).
Lacey and Ouvry (1998:168) found that the stress might be increased by the failure of service providers to give sufficient support to meet the needs of the caregivers. Sartorius and Graham (1984:211) advise that more research be conducted in areas of mental health assessment of children. The epidemiology of severe retardation, especially in developing countries as well as the coping strategies of families, especially those used by mothers with the "outer reality" of having a mentally retarded child, and the "inner reality" of feeling the loss of a desired, normal child. In South Africa, Davids (1992 in Maluleke, 1993) did similar studies among coloured families in Cape Town, Van Staden and Gerhardt (1994) among white families in Pretoria. and Maluleke (1993) among black families with profoundly retarded children in Katlehong Township near Germiston. In Namibia, no study ever investigated the experiences of mothers caring for mentally retarded children in the township. The study that led to this article was therefore a realisation of the need to explore the experiences of mothers who care for mentally retarded children in the Katutura Township near Windhoek and to discover inherent stressors and their coping strategies.

\section{Research design}

A qualitative, explorative, descriptive and contextual design was used to explore and describe the experiences of caring for a mentally retarded child at home as lived by their mothers in the township in Namibia. The researcher used the phenomenological approach of the qualitative paradigm.

\section{- A purposive or judgemental} sampling method (Burns \& Grove, 1997:306) to include those who met the criteria of selection and who were willing to participate was used in the selection of the respondents.

- $\quad$ Twelve phenomenological interviews were conducted with mothers of mentally retarded children residing at Katutura Township who looked after their children at home;

In addition, the respondents had to be able to communicate in either Afrikaans or English.

The choice of the two languages was based on the fact that the researcher is proficient in them; 
and that in Namibia there are about eleven indigenous languages spoken, however, the most used language to communicate by people of different ethnic backgrounds is Afrikaans. She observed in her many years of stay in Namibia that even children learn their home languages (indigenous) simultaneously with Afrikaans. Most toddlers are Afrikaans language proficient by the time they go to preschool. English is the official language and thus most literate people speak it. Sandelowski (1995:180) maintains that in qualitative research, events, experience, and not people per se, are the object of purposive sampling.

The mentally retarded children had to be of the age ranges six $t$ o eighteen years (6-18 years), because some forms of mental retardation can only be detected at school going age (Leadbetter \& Leadbetter, 1993:117);

- In addition, the mentally retarded children were not to be at a day care centre. In this study the researcher deliberately excluded the levels or degrees of mental retardation of the children because in Namibia there is no state funded facility for IQ testing

\section{Ethical measures}

Informed consent was obtained from all participants by explaining the goals of the investigation, the possible advantages and disadvantages of participating, and the credibility of the researcher who would conduct the interviews. The participants were assured of confidentiality and anonymity, as they were not going to be identified in the research report. The ethics committee of the Faculty of Health Sciences at the University of Free State approved the research project.

\section{Trustworthiness}

Guba's model for trustworthiness suggests ways of reducing bias in the results (Poggenpoel \& Myburgh, 1998:349). The model identifies four aspects of trustworthiness: Truth-value, Applicability, Consistency, and Neutrality.
The researcher ensured that she uncovers the truth of the experiences of mothers who care for their mentally retarded children in the township, by being immersed in the setting for a prolonged period, conducting interviews, observing and taking field notes for an hour and more with each participant. She used strategies like triangulation of methods (interviews and observation), long engagement in data collection to get more clarity, obtaining feedback from participants after reading the research report (member-checks) to increase the credibility of the study.

The interviews were conducted in a "naturalistic setting" (Krefting, 1991:216), at the homes of each participants and the situation was unique in each instance thus the findings could not be generalized. However, the researcher enhanced the applicability (transferability) of the study by safeguarding all data- transcriptions, analysed data records, interview cassettes and the independent coder's analysis and consensus discussion records.

To adhere to the criterion of consistency (dependability), the researcher conducted two pilot studies and then interviewed several participants until saturation of data was reached, when the same themes started reappearing in the data. She watched the variability of the interview encounter by noting personal, theoretical, elective notes and observations that were included in the findings of the study (Krefting. 1991:216). Neutrality is the fourth criterion of trustworthiness; it is the freedom from bias in the research process and results. To ensure objectivity the researcher's findings were a function solely of the informants and conditions of the research and not the function of the researcher. To ensure that the data and the analysis thereof are free from bias she adhered to rigor of the methodology. The data was confirmable as a product of the phenomenological narratives of the participants. She postponed any review of literature until the data was analysed.

\section{Sampling method}

Participants in the study were included by way of "purposive or judgemental sampling", a non-probability sampling method which involves a conscious selection of participants (Burns \& Grove, 1997:306). The research sample met the criteria of selection and was willing to participate. The mothers had to be residing at the Katutura Township and caring for their mentally retarded interviews were children at home. The mentally retarded children were not to be at a day care centre as the study objective was to discover the coping measures of mothers in looking after the children at home. They had to be able to communicate in either Afrikaans or English.

The choice of the two languages was because the researcher is proficient in these languages. In Namibia, there are about eleven indigenous languages spoken, however the language most used to communicate by people of different ethnic backgrounds, is Afrikaans. Twelve open-ended interviews were conducted with mothers of mentally retarded children. According to Sandelowski (1995:180), when using qualitative research, events and experiences and not people per se, are the objects of purposive sampling. The mentally retarded children had to be of the age ranges six to eighteen years, because some forms of mental retardation can only be detected at school going age (Leadbetter \& Leadbetter. 1993:117). The level or degree of mental retardation of the children was excluded because in Namibia there is no state-funded facility for IQ testing.

\section{Description of the sample}

The sample in the study comprised of twelve participants. All were mothers of one or more mentally retarded children. They were of different age and cultural background (see Table 1.1).

\section{Data collection method}

The researcher conducted phenomenological interviews with twelve participants until there was evident repetition of discovered information and confirmation of earlier data, in other words saturation (Streubert \& Capenter, 1995:24). One central question was used, namely: "How do you experience caring for your mentally retarded child at home?" (Hoe beleef u die versorging van u verstandelik gestremde kind by die huis?).

An audiotape was used to collect and capture data. The respondents did not express any problems with the use thereof nor the taking of notes (observational, theoretical, methodological and personal). Data were later transcribed verbatim from the tapes. A working relationship with the respondents was developed by cultivating their goodwill and by 
TABLE 1.1 Demographic information of the sample $(\mathrm{N}=12)$

\begin{tabular}{|l|ll|l|l|}
\hline CRITERION & \multicolumn{1}{|l|}{ CHARACTERISTICS } & FREQUENCY & PERCENTAGE \\
\hline \multirow{2}{*}{ Age } & - & $20-30$ & 4 & $33 \%$ \\
& - & $31-40$ & 2 & $17 \%$ \\
& - & $41-50$ & 6 & $50 \%$ \\
\hline \multirow{2}{*}{ Marital status } & - & Married & 4 & $33 \%$ \\
& - & Single & 8 & $67 \%$ \\
\hline \multirow{2}{*}{ Ethnicity } & - & Baster & 2 & $17 \%$ \\
& - & Damara & 1 & $8 \%$ \\
& - & Herero & 5 & $42 \%$ \\
& - & Nama & 1 & $8 \%$ \\
& - & Owambo2 & 3 & $25 \%$ \\
\hline Language & - & English & 7 & $58 \%$ \\
Preference & - & Afrikaans & 5 & $42 \%$ \\
& &
\end{tabular}

contouring the researcher's behaviour to fit in with them and reducing social distance (Wilson, 1989:424) (e.g. by wearing simple home clothes whenever going to conduct the interviews in order to bridge differences).

Phenomenological reduction or bracketing was used during the interviewing process (Kvale, 1983:184185; Streubert \& Capenter, 1995:44). Trust and rapport were attained by using communication and therapeutic skills, empathy, congruence, and genuine acceptance (Uys \& Middleton, 2004:144). The interviews were carried out in the relaxed atmosphere of the respondents' own homes, thus genuine cooperation was obtained. The engagement was also prolonged and extensive (spending at least an hour per respondent). Field notes were kept during the investigation. These notes consisted of observations made during the interviews.

\section{Data analysis}

Data were not analysed until all interviews had been completed, that is when no more new experiences were reported and information redundancy or theoretical saturation was attained (Lincoln \& Guba. 1985:201). The methods suggested by Sandelowski (1995:182) for proofing the transcripts were used. The audiotaped interviews were listened to repeatedly, comparing them with the transcriptions. During this process, key phrases were pointed out and sentences and even feelings expressed by the respondents were noted. After proofing the transcripts, information was sorted into categories to form a story (Creswell.
1994:153).

The Tesch (1990) steps of analysing qualitative data guided the data analysis process. Creswell (1994:155) outlines the steps as:

- $\quad$ Getting a sense of the whole by reading through all the transcriptions carefully and jotting down ideas;

- $\quad$ Picking the most interesting interview and considering its content;

- Categorising topics as major, unique and "leftovers"; abbreviating the topics as codes and writing the codes next to the appropriate segments of the text, and then trying out this preliminary organising scheme to see whether new categories and codes emerge:

- $\quad$ Finding the most descriptive wording for the topics and turning them into categories and grouping topics that relate to each other in order to reduce the total list of categories;

- Make a final decision on the abbreviation of each category and placing codes in alphabetic manner; and

- $\quad$ Assembling the data belonging to each category in one place and performing a preliminary analysis.

The transcriptions together with field notes were sent to an "independent coder" (Creswell, 1994:158) for analysis. The independent coder was an experienced researcher who previously had supervised several qualitative studies of postgraduate nurses. There was a consensus discussion of the independent findings of the investigator and the co-coder. The coding process led to the emergence of themes, which were refined during the consensus discussion with the co-coder.

The researcher and the co-coder agreed on the categories, subcategories and the themes identified in the transcriptions. These may be found on Figure 1.1.

Data from the interview transcripts were grouped into five main categories (emotions, relationships, social circumstances, physical needs and support) and subcategories. Themes were identified and developed to substantiate each category.

The details of the participants' relating of their experiences in caring for mentally retarded children may be found in Table 1.2. The subcategories and themes were grouped together as pleasant and unpleasant experiences, in order to make the discussion brief.

This study revealed pleasant and unpleasant experiences in caring for the mentally retarded children by their mothers. This is consistent with the study by Hilbert, Walker and Rinehart (2000:158) who studied the responses of parents caring for children with the Sturge-Weber syndrome (a rare, progressive congenital condition marked by developmental delays, seizures and cerebral haemorrhage). The latter study revealed both positive and negative aspects of caring. There was the dimension of satisfaction and self-worth the caregiver may derive. This is the positive aspect. There was also the burden and hardships of caring. This is the negative aspect.

\section{Results and discussion}

The discussion will be based on the schematic condensation of the data in Table 1.2. The discussion will be highlighted by direct quotations from the participants and accompanying literature control.

\section{Category l: Emotions Acceptance and love}

It is significant that in all transcribed interviews, participants verbalized their feelings of acceptance and love. This is evident from statements such as: "I 


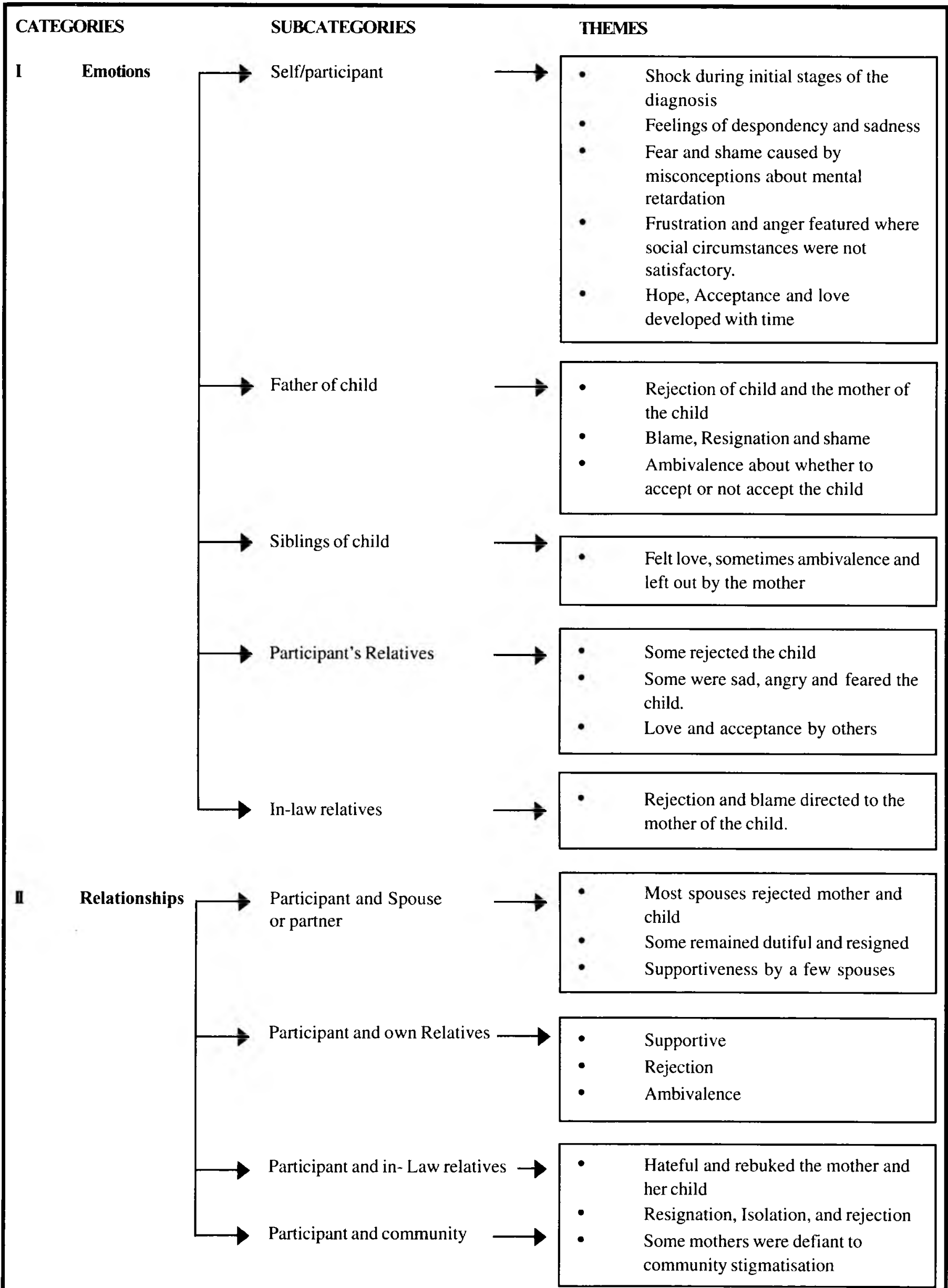




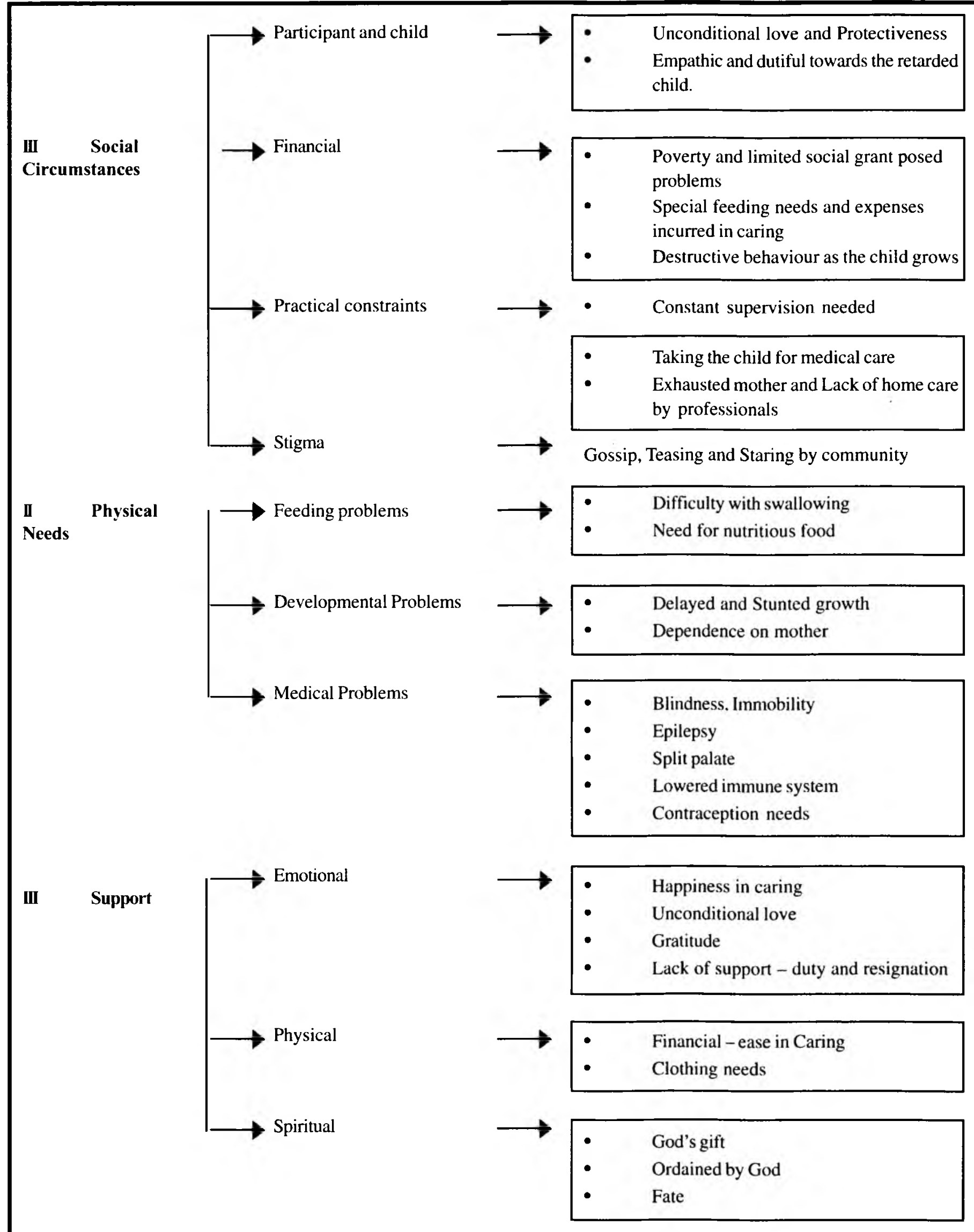

have accepted the situation, I love my child"

In this sub-category, the mothers regarding their happiness in caring for their mentally retarded children made much reference.

"I am very happy with my child".
Also in this subcategory, it was clear that this acceptance and love comes over time. In the early stages, all the participants tell a story of how it was difficult in the beginning, but as time went on, they became more resigned and accepting. This is evidenced by quotations like
"Maar met jare het maar aangepas aan alles" (With time we adapted to everything).

This experience is supported by the findings of Maluleke (1993:57-59) who studied the effect a physically handicapped child has on family 
functioning in Katlehong Township. Acceptance and love for the child ultimately was attained, but much stress was experienced when the children were still young.

\section{Feelings of despondency and sadness}

These feelings were universal to mothers during the early stages when the retarded children were still young. The following direct quotation highlights this aspect: "I could have died that time; I could have felt better"

Some participants describe how their sadness and despondency was preceded by a state of shock:

"Toe ek vir haar vir die eerste keer gesien het, het ek benoud gevoel" (When I saw her for the first time, I caught my breath).

Some participants described how in their despondency and sadness tried to deny the experience:

"For a long time I thought the sister gave a wrong child"

Some mothers still expressed the feelings of despondency and sadness after many years, long after the stage of acceptance. This became clear from statements like "Soms is dit moeilik om te sê vandaag is "n mooi dag..." (At times it is difficult to say today is a beautiful day).

This finding is consistent with that of Mallow and Bechtel (1999:31) who studied chronic sorrow experienced by parents with children who are developmentally disabled. These researchers described the period when the child is initially diagnosed as one of crisis and disequilibrium and may have an impact on family functioning and cohesion. Joubert (1988:164) studied intervention strategies and theoretical approaches in assisting families with mentally retarded children. She refers to responses ranging from shock, sadness, disappointment, hopelessness and chronic sorrow.

\section{Fear and shame}

In this theme, a strong trend emerged that there were many misconceptions about the cause of mental retardation, mainly due to ignorance. Most participants saw it as somebody's fault. someone had to be blamed and it was shameful. The following quotations demonstrate this: "When he saw' my' child maybe he became afraid."

"I was ashamed to talk about my child" Some families were ashamed and this was part of their rejection:

"Mv own family feel strange and fear to touch my child"

The community did not feel shamed because it is not their own family; they wanted nothing to do with the mother and her mentally retarded child or children. They lacked understanding and they mocked the children. This is clear from the quotation below: "Soos die skoolkinders vir haar so terg, moet ek haar in die huis probeer hou." (Because of teasing by schoolchildren, I must try to keep her inside the house).

Herrick, Pearcey and Ross (1997:22-23) studied stigma and ageism. They found that stigma is associated with the devaluation of a person because he /she are different. The fear and shame experienced by mothers in this study was clearly associated with the stigmatisation by the community. Hannam (1980:67) studied parents of handicapped children and he found that parents expressed fear and shame to ask for babysitters because they would have to deal with soiled bedding of the handicapped child.

\section{Anger and frustration}

The theme of anger and frustration featured predominantly in participants whose social circumstances were not satisfactory. Financial difficulties contributed to feelings of entrapment and not having life. Where there was family or spouse support and financial adequacy the feelings of anger and frustration was less. Anger and frustration were manifested in statements like: "Mv life is affected too much. I cannot have a normal life". "I cannot go anywhere. No one comes to see me".

Mallow and Bechtel found similar experiences among fathers of children with developmental disabilities. Fathers' emotions turned to frustration and resignation, while the mothers experienced a greater resurgence and intensity of sorrow. Hibert et al (2000:159) found that mothers of disabled children who received less emotional support from family and friends felt more frustration and functioned poorly.

\section{Worry}

Mothers clearly expressed worry about various issues, like

"And if he dies, he is not baptised...my child won 't go to God."

"Ek dink ook daaraan wat sal gebeur as sy erger raak en ek het nie meer krag om haar te hanteer nie" (I think a lot about what will happen when she gets worse and my strength is too frail to control her).

"I cannot work now', but I don't know when my child will be better."

Hannam (1980:67) found that when there were small children as well as the mentally retarded child there was always the worry and fear that this child would harm the others. Worry about the well-being of the mentally retarded child and that of the family members is similar to the worry expressed by families of mentally ill members (Ip \& MacKenzie, 1998:290-291; Sveinbjarndottir \& de Casterlé, 1997:45 and Rose, 1997:23). Maluleke (1993:57) found that another source of worry and distress for the parents of physically handicapped children was the lack of specialised schools in the township.

Spouse / Partner unconditional acceptance and love.

Spouses and partners of the participants in this study were significantly rejecting and ambivalent; however, three out of twelve expressed unconditional acceptance and love to the mother and the mentally retarded child. Typically, these fathers were protective, supportive, available, shared responsibility and were caring. The boundaries between these fathers and the mother-mentally retarded child/children were open. They shared the mother-child context, yet they still had their lives outside this context. This phenomenon is explained by quotations such as:

"He loves the child very much and he gave her his mother's name" "Sy is baie aan die pa se hart, meer as al die ander kinders" (She is very close to the father's heart more than all the other children)

"He spends most of the time at work, he understands and accepts the situation. He goes to places alone, funerals, weddings, church and even shopping" The phenomenon of acceptance and love by the spouse also played a very decisive role in positioning the mother along the continuum. In this study, mothers of mentally retarded children whose spouses / partners showed love and acceptance were happy, not isolated, were integrated and were defiant to stigma and had no shame.

Nowhere in the literature reviewed was there mention of spousal or partner rejection. However. Mallow and Bechtel (1999:32) cited work by Newacheck and Halfon (1998) who studied families with chronically ill children. They found that chronic illness in children adversely affected family healthy patterns. The mothers' emotions most often radiated 
into chronic sorrow while fathers' reactions moved into resignation. Hannam (1980:69) also found that the burden of caring for the mentally retarded child fell on the mothers, for them there was no escape. The fathers could at least get away to work, and immerse themselves in it and forget the problems at home for a while.

\section{Category II: Relationships Protectiveness}

There were dynamics of love, care and protectiveness on most participants' verbalizations; these were often differently motivated. Some of them were motivated by duty:

"Daarom voel ek, ek is die enigste ene wat vir my kind kan sorg". (Hence I feel, I am the only suitable one to care for my child)

Some of them were motivated by pure love:

"I can only feel love, real protecting love for my little ones"

Some of them were motivated by guilt: "I feel bad that I bring only problems to my sister, but I care for my child"

Some of them were motivated by the belief that they are simply ordained:

"God gave me such a child, so I will just help my child"

Hannam ( 1980:67) also found that parents of mentally handicapped children were very protective and would not even entrust them to someone to sit in for them. Most families in the same study reported over-indulgence over the handicapped child and almost neglect of their siblings.

\section{Rejection by spouse / partner}

Most of the fathers of the children in this study rejected the mother and her child or children and decided not to have anything to do with them. Some partners and spouses disappeared from the context of the mother and her mentally retarded child or children. The rejection is about blame, fear, shame and ignorance. The rejection was evidenced by quotations like

"I went to his home several times to ask for money but he becomes angry and savs this is not his child".

"Hy het al vyf beeste vir my ma gegee, ons sou getrou het, maar na die haba. hy het dit nie meer genoem nie. " (He had paid five cattle to my mother, we were to marry, but after the baby, he never mentioned it again).

Some fathers became resigned and ambivalent; they only performed their basic duties
"Ek sal nie kan sê hy het my kind lief nie, want hy gee net kos en klere maar. hy soek nie die kind naby hom nie" (I cannot say he loves the child. because he only gives food and clothes but does not want the child near him).

Mallow and Bechtel (1999:32) cite similar reactions in their study. They reported changes in the marital relationship due to care for the developmentally disabled child being linked to paternal feelings of exclusion and inferiority in the father role. Hilbert, Walker and Rinehart (2000:158) also reported that caring for a developmentally disabled child requires the adjustment of schedules, roles of family members and patterns of parental intimacy. Hannam (1980:69) reported that relationships in other houses were strained, because of broken night sleep, when the child had been naughty or sick. Rejection by in-law relatives

The theme of rejection by in-laws appeared significantly in the data and interestingly there was no one mention of an accepting or supportive in-law family. The participants either mentioned rejection by in-laws or did not refer to them at all. Feelings expressed regarding in-laws were

"If my child was normal I know' they would help me"

"Oe! Sy ma is my doodkis se spyker...sy ma sê ek is "n heks" (Oh! His mother is a nail on my coffin... she says I am a withe).

Katwishi (1998:256-257), found similar results in Zambia. The in-law family would insist that the fathers of handicapped children should leave their wives and marry new wives. Consistent with this study is that this researcher maintained that the rejection was also about blame, ignorance and lack of understanding. Hannam (1980:67) also found that not all mothers and mothers in-law were an ideal source of help, some in-law families especially mothers in-law were very supportive, yet other own families were not supportive at all. Contrary to these study findings, Hilbert et al. (2000:164) found that there was lack of own family support and that the lack of family support in their study was significantly correlated with esteem.

\section{Category III: Social Circumstances}

\section{Poverty and financial problems}

This theme emerged almost exclusively in the initial phases of seven interview transcripts. Poverty and financial problems seem to be responsible for feelings of despair and isolation. Statements such as evidenced this:

"If someone did not give me her old napkins and clothes for her baby, I suffer"

"Hy' gee haie min geld vir onderhoud." (He gives very little money for support).

Hilbert et al. (2000:158) also found that family energy and especially resources are consumed in the care giving, there was need for adjustment of schedules, medical care consumed much of the family resources, and the mothers had to abandon their jobs for the sake of the child. Hannam (1980:69) found similar results, the main burden fell on the mothers, and the fathers could at least get away to work. McCubbin (1989:102) compared single and two-parent families with handicapped children; she found that single-parent families were a vulnerable group who may be in need of more support and guidance from health and social services. Failla and Jones (1991:47-48) found that to the contrary older mother groups who significantly had more income, experienced more financial problems because of the additional strain of having more family members, they had more children thus they found it difficult to meet the challenge of rearing a child with a developmental disability.

\section{Practical constraints in caring}

Most of the participants in this study hinted at one or more problems to meet the physical needs of their mentally retarded children. Physical care, which comprised a number of different elements, like feeding, mobility, behaviour patterns, contraception needs, illness, stimulation. elimination, washing dressing etc. The constraints in caring were evidenced by statements such as: "K.'k hoe lyk my hande, van elke dag se wux.." (Look how my hands look like, from every day's washing).

"I must watch him when he fall (fits) not to hurt himself"

Most literature reviewed hinted at the high levels of stress related to the direct care giving (Hilbert et al, 2000:159; Hannam, 1980:67; Sveinbjarndottir \& de Casterlé. 1997:45; Ip \& MacKenzie, 1998:288). All studies described the child presenting difficulties with sleep, feeding, incontinence, speech problems, constant illness, behaviour problems etc. Parents of older children in the literature reviewed 


\begin{tabular}{|c|c|}
\hline MAINCATEGORIES & Clustering of themes into pleasant and unpleasant experiences \\
\hline Emotions & $\begin{array}{l}\text { Acceptance and love } \\
\text { Feelings of despondency and sadness } \\
\text { Fear and shame } \\
\text { Anger and frustration } \\
\text { Worry } \\
\text { Spouse / partner unconditional acceptance and love } \\
\text { Spouse / partner guilt }\end{array}$ \\
\hline Relationships & $\begin{array}{l}\text { Protectiveness } \\
\text { Rejection by spouse / partner } \\
\text { Rejection by in-law relatives }\end{array}$ \\
\hline Social circumstances & $\begin{array}{l}\text { Poverty and financial problems } \\
\text { Practical constraints in caring } \\
\text { Stigma } \\
\text { Physical / needs Problems of development } \\
\text { Medical and behavioural problems } \\
\text { Support Religion as spiritual support } \\
\text { Physical and emotional support } \\
\text { Bravery and defiance to stigma }\end{array}$ \\
\hline
\end{tabular}

expressed similar concerns as the mothers in this study, fears that the child might fall pregnant. puberty and sexual development. swings of mood. hostility and violence. Hannam (1980:130) noted that some parents became embarrassed when menstruation began for girls and the masturbation of boys disturbed them.

\section{Stigma}

The theme of stigma was a phenomenon that ran through all participants though some described it more explicitly - the rejecting spouse / partner, in-law family and the section of the community. saw the mother and her mentally retarded child or children as blameworthy. bad and guilty. The stigma was expressed in quotations such as:

"My neighbours don't know them. Even if they can talk, they talk about something they have not seen"

"I cannot take her anywhere then people will gossip"

Stigma was the cause of entrapment and isolation on the mothers, as expressed in the following quotations:

"My children are my social life. I hav'e no life beyond that gate"

"Ek het nie geselskap nie... ek het so min mense wat na my toe kom". (I don't have conversation... very few people come to me).

"I cannot dress up nicely, to go where?" Stigma is a social construct and the person with stigma becomes not quiet human and inferior to society; the stigmatized people tend to hold the same beliefs about their identities as the rejecting groups do (Goffman. 1963:3-5), Inferiority surrounding the person provokes animosity from others based on the person's difference. Consequently, the person becomes stigmatized by society (Herrick et al, 1997:22). This was also evident in families of mentally ill members (Rose. 1997:18; Hines-Martin, 1998:439; Ip \& MacKenzie, 1998:292). Failla \& Jones (1991:41) found that chronic stressors that affect families of children with special health care needs included among other things the stigma attached to these children.

\section{Category IV: Physical / needs \\ Problems of development}

Clear, direct statements from a significant number of participants as a problem characterized this theme. Problems mentioned included toilet training, feeding, walking and incontinence.

"She is like a small baby, but she is six years old now"

"...Eintlik, hy is baie stadig met alles". (Actually, he is very slow in everything). "Ek wens hy kon geloop het..." (I wish he could walk...).

Joubert (1988:166) found that many parents despaired when the children progressed slowly through the different developmental stages. In the same study, parents described other problems like sleep, incontinence and constant illness as added burdens on especially the mothers.

Medical and behavioural problems This theme clearly indicated that the mothers' experiences were more difficult where there were behavioural problems and / or other medical conditions. In those cases, there was clearly a sense of less love and empathy, but more duty and resignation. The following statements are evidence to this effect from some participants:

"Sy gooi mense dakke, mense se karre met klippe...daardie tyd voel ek, ek kan vir haar doodslaan..." (She throws stones at people's roofs and cars; at that moment, I feel I could hit her to death).

"Daar is wel due wanneer ek voel ek kan hom vir die pa gaan gee..." (Well. there are days when I feel I could give him to his father...).

Hannam (1980:96-103) gave an explicit picture of difficulties parents experience when the children have medical and behavioural problems, like rocking, screaming, spilling things, scribbling on the wall, running into the streets. Mothers of adolescent mentally retarded girls expressed fear of pregnancy and sexual molestation.

"Ek sien sommige jong manne wat sê, Handjievol jy is my vrou, dan voel sy. 
lekker en dink hulle bedoel dit" (I see some young men saying, Handjievol you are my wife, then she feels happy and think they mean it).

\section{Category V: Support}

In this study support of any form or lack thereof was the decisive factor positioning mothers along a continuum of two extremes, namely the one end of despairing isolation and that of integrated happiness.

\section{Religion as spiritual support}

Mothers and their mentally retarded children who enjoyed support from family members and other social structures expressed uttering like:

"I thank God for my mother... she is always there for me".

"This is God's own gift, where can you find a man like that; he feeds us, dresses us and made this beautiful home for us". "My priest also gives me lots of support, prayers, he visits us every fortnight".

\section{Physical and emotional support}

A few participants in this study received support from the community, particularly the church. Interestingly, there was no mention of community- or psychiatric nurse support. The community support was expressed in the following quotations:

"The church people helped me; they gave me that washing machine..."

"I wish we had doctors coming to the houses, like those older days".

Hannam (1980:67) viewed family coping when there was mental retardation as movement along a continuum. He identified two extremes, the "solids", those with resource enough to cope and who can fall back on other members of the family. In addition, there are the "brittles", who are shattered and helpless, who need much support from outside agencies. Hilbert et al. (2000:159) found that poorly functioning mothers of disabled children were in poorer physical and mental health, and received less emotional support from family and friends than do well adapted mothers receive. McCubbin (1989:102) found that spousal support played a key role in moderating the stress in families with handicapped children.

\section{Bravery and defiance to stigma}

In this study, not all mothers became isolated, entrapped and timid from stigma; some became defiant, brave and challenging to the stigma. The defiant attitude was noted in verbalizations like: "I sit my child outside here in the veranda without worry of people passing...let them look...I love him"

"Ek loop oral met haar saam. Hoekom moet ek vir haar wegsteed?" (I go everywhere with her. Why should I hide her?).

These defiant mothers typically enjoyed support and love from their spouses / partners. Where there was emotional or physical support, love and care, availability of the spouse or partner, shared responsibility and unconditional acceptance, the mother and her mentally retarded child or children did not feel isolated; they were integrated and happy.

McCubbin (1989:101) found that there was clearly altered family relationships and among other things social isolation where families had handicapped children. Hannam (1980:69) found that the burden of caring for the mentally retarded child fell more on the mothers, for them there was no escape. The fathers could at least get away to work, and immerse themselves in it and forget the problems at home for a while.

Support seemed to play a key role in moderating the stress, promoting coping and the effective management of the hardship in caring for the mentally retarded children (McCubbin, 1989:102; Rose, 1997:17; Mallow \& Bechtel, 1999:31).

\section{Conclusion}

The findings of the study leading to this article showed that the initial caring for a mentally retarded child at home is a strain on the family, especially the mother. The respondents reported that the birth of the child and subsequent diagnosis of mental retardation were met with shock. All respondents experienced feelings of anger, frustration, fear, worry, blame, guilt, helplessness, resignation and sadness. Encouraging was the fact that this period of disorganisation passed with time. The mothers and a few fathers returned to an emotional equilibrium after a while. However, this seemed not to be the end of the mothers' feelings and responses about having a mentally retarded child.

Rearing a mentally retarded child seemed to be a continuous process, and each phase of life brought its own demands and problems resulting in traumatic emotional problems for the parents, especially the mother. It was found in the study that most fathers rejected the mother and her mentally retarded child. The in-law relatives of all respondents did not want anything to do with the mothers and their children. The research found that some mothers enjoyed the support of their own relatives (own mother and sisters). The study also revealed the importance of spousal physical and emotional support. The mothers who enjoyed support from their husbands or partners seemed to cope better and were able to manage the hardships of caring for the mentally retarded children.

It is worth noting that the study leading to this article was conducted only in the urban area of the Katutura Township. It would be advisable to investigate this phenomenon in a rural setting in Namibia, to enable appropriate mental health interventions to all areas of the country.

\section{Recommendations}

Based on the results and conclusions of the study, which led to this article, the following recommendations and incorporated guidelines were made:

- $\quad$ There is a need to initiate a mental health education programme in the Katutura Township, which should address the needs of mothers of mentally retarded children and their families. The Mental Health Programme of the Ministry of Health and Social Services in Namibia should include the subject of mental retardation in their existing mass media presentations.

- The introduction of a community psychiatric nursing service aimed at assisting this population of mothers and their mentally retarded children would make a difference to the mothers' hardships. The community psychiatric nurses should work closely with CHAIN.

- Financial assistance in the form of a social grant would help ease some of the hardships. The Social Service division should not wait until the child is 16 years old, as the criterion currently stipulates. Social workers should also provide counselling services. Initiating a self-help group and providing group 
psychotherapy would help ease the hardships of the mothers. The Faculties of Health and Social Sciences at the University of Namibia could use the self-help group for clinical practice of their students (i.e. students in Psychiatric Nursing, Physiotherapy and Occupational Therapy, Psychology and Social Work).

\section{Acknowledgements}

The researcher wishes to express her sincere gratitude to the mothers who allowed her to come into their homes and who gave her time for an interview.

\section{References}

BURNS, N \& GROVE, SK 1997. The practice of nursing research - conduct, critique and utilization. $3^{\text {rd }}$ edn. Philadelphia: WB Saunders.

BAUMANN, SE 1998. Psychiatry and primary health care. Kenwyn: Juta \& Company.

CRESWELL, JW 1994. Research design qualitative and quantitative approaches. London: Sage Publications.

DE VOS,AS; STRYDOM, H; FOUCHÉ, CB; POGGENPOEL, M \& SHURINK, EW 1998. Research at grass roots - A primer for caring professions. Pretoria: JL van Schaik.

FAILLA, S \& JONES, LC 1991. Families of children with developmental disabilities: An examination of family hardiness. Research in Nursing and Health. 14(1), February: 41-50

GENERAL REPUBLIC OF NAMIBIA Ministry of Health and Social Services: Directive 002/1998 (GRN/MHSS 002/98) on Mental Health Services.

HANNAM, C 1980. Parents and mentally handicapped children. Suffolk: Penguin Books.

HERRICK, CA; PEARCEY, LG \& ROSS, C 1997. Stigma and ageism: Compounding influences in making an accurate mental health assessment. Nursing Forum. July-Sept. 32(3):21-32.

HILBERT, GA; WALKER, MB \& RINEHART, J 2000. "In for the long haul". Responses of parents caring for children with Sturge-Weber syndrome. Journal of Familv Nursing. 612). May: 157179.

HINES-MARTIN， VP 1998. Environmental context of care giving for severely mentally ill adults: An African American experience. Mental Health Nursing. 19(5), September-October: 433450.

IP, GSH \& MackENZIE, AE 1998. Caring for relatives with serious mental illness at home: The experiences of family carers in Hong Kong. Archives of Psvchiatric Nursing. XII (5). October: 288294.

JOUBERT, L 1988. Social work and the parent of the mentally handicapped child. Social Work Professional Journal. 24(3), August: 16-169.

KATWISHI, SM 1998. The impact of impairments on childcare and development in Zambia. Paper Windhoek. Fourth International Conference for the study of Behavioural Development. July.

KREFTING, L 1991. Rigor in qualitative research - The assessment of trustworthiness. The American Journal of Occupational Therapy. 45(3): 214-222

KVALE, S 1996. Interviews: An introduction to qualitative research interview. London: Sage.

KVALE, S 1983. The qualitative research interview: A phenomenological and a hermeneutical mode of understanding. Journal of Phenomenological Psvchologv. 14:171-190.

LACEY, P \& OUVRY, C 1998. People with profound and multiple learning disabilities - A collaborative approach to meet complex needs. London: David Fution Publishers.

LEA, SJ 1989. The relationship between parents and their institutionalised mentally handicapped child. Social Work -Professional Joumal. 25(4), October: 5670.

LEADBETTER, J \& LEADBETTER, P 1993. Special children - Meeting the challenge in the primary school. London: Cassell.

LINCOLN, YS \& GUBA, EG 1985.
Naturalistic inquiry. London: Sage Publications.

MALLOW, GE \& BECHTEL, GA 1999.

Chronic sorrow: The experience of parents with children who are developmentally disabled. Journal of Psvchosocial Nursing. 37(7), July: 31-35.

MALULEKE, ED 1993. The effect a physically handicapped child has on family functioning. (MA [Soc.Sc.] dissertation). Johannesburg: Rand Afrikaans University.

McCUBBIN, MA 1989. Family stress and family strengths: A comparison of single and two-parent families with handicapped children. Research in Nursing and Health. 12(2), April: 101-110.

METRO-2000. "Help ons kan nie meer nie." Windhoek (Afrikaans daily newspaper), 18 May.

POGGENPOEL,M \& MYBURGH,CHP 1998. The developmental implications of abortion of adolescents with reference to the girl and her partner. Unpublished paper. Windhoek (International Study of Behavioural Development Conference).

ROSE, LE 1997. Caring for caregivers: Perceptions of social support. Journal of Psychosocial Nursing and Mental Health Services, 35(2), February: 17-24.

SANDELOWSKI, M 1995. Focus on qualitative methods. Sample size in qualitative research. Research in Nursing and Health. 18:179-183.

SARTORIUS, N \& GRAHAM, P 1984. Child mental health: experience of eight countries. WHO Chronicle. 38:39-60

STREUBERT, HJ \& CARPENTER, DR 1995. Qualitative research in nursing Advancing the humanistic imperative. Philadelphia: JB Lippincott.

SVEINBJARDOTTIR，E \& DE CASTERLÉ, ED 1997. Mental illness in the family: An emotional experience. Issues in Mental Health Nursing. 18 , January-February: 45-56

UYS, L \& Middleton, L 2004. Mental health nursing - A South African perspective. $4^{\text {th }}$ edition. Cape Town: Juta.

VAN STADEN, F \& GERHARDT, C 1994. Mothers of children with facial cleft 
deformities. Reactions and effects. Social Work Professional Journal. 27(3) March: 114200.

VRANCKX, C 1996. Draft Policy for Mental Health. Windhoek: Ministry of Health and Social Services.

W'ILSON, HS 1989. Research in nursing. $2^{\text {nd }}$ edition. Redwood City, California: Addison-Wesley. 